NBER WORKING PAPER SERIES

EMPLOYMENT AND OCCUPATIONAL ADVANCE

UNDER AFFIRMATIVE ACTION

Jonathan S. Leonard

Working Paper No. 1270

NATIONAL BUREAU OF ECONOMIC RESEARCH 1050 Massachusetts Avenue

Cambridge, MA 02138

February 1984

I thank Richard Freeman, Zvi Griliches, Finis Welch, and Jim Smith for their comments. This research was supported in part by the Office of the Assistant Secretary for Policy Evaluation of the U.S. Department of Labor, and the School of Business Administration, University of California at Berkeley. Points of view or opinions stated here do not necessarily represent the offical position or policy of the Department of Labor or the University of California. The research reported here is part of the NBER's research program in Labor Studies. Any opinions expressed are those of the author and not those of the National Bureau of Economic Research. 


\title{
Employment and Occupational Advance \\ Under Affirmative Action
}

\begin{abstract}
Affirmative Action is not only supposed to help move minorities and females into employment, it is also supposed to help move them up the job ladder, and it is this second goal that is perhaps the more controversial. Studies of Affirmative Action during the late 1960's and early 1970's found it generally ineffective in the white-collar and skilled occupations. Using disaggregated employment data in a new sample of nearly 70,000 establishments, this study finds that Affirmative Action was generally successful during the late $1970^{\prime}$ 's in increasing minority employment in skilled white-collar occupations as well as in unskilled jobs.
\end{abstract}

Jonathan S. Leonard 350 Barrows Hall School of Business Administration University of California Berkeley, CA 94720 (415) 642-7048 
To protest employment discrimination at the beginning of World War II. A. Philip Randolph, President of the Sleeping Car Porters Union, threatened to disrupt the defense effort by a mass demonstration of blacks in Washington D.C. on July 1, 1941. Less than one week before the planned rally. President Roosevelt issued Executive Order 8802 barring discrimination by federal contractors and the demonstration was called off. The partial accommodation reached in the atmosphere of discord and crisis of that Executive Order established the roots of a policy that I shall argue is today bearing fruit: that policy is affirmative action.

One of the major affirmative action battlefields lies in the white-collar and craft occupations. It is in these skilled positions that employers are most sensitive to productivity differences and have complained the most about the burden of goals for minority and female employment. It is also in this region of relatively inelastic supply that the potential wage gains to members of protected groups are the greatest. The handful of past studies in this area have unanimously concluded that affirmative action has been ineffective in occupational upgrading and that the employment gains it has engendered for minorities have been concentrated in low skill positions. For the late nineteen-seventies this paper shall argue the opposite, using a new detailed set of data on changes in establishment level demographics covering more than 16 million employees between 1974 and 1980.

Four previous studies of affirmative action between 1966 and 1973 are reviewed in Section 1, which then develops a model of affrmative action as a tax on white male employment. Section 2 presents evidence of the impact of the contract compliance program on total employment by race and sex. The third section discusses the main findings on occupational advance under affrmative action. To show the impact of affirmative action on occupational upgrading, three tests are presented in section 3. First, a summary measure of occupational status, an occupational index, is constructed for each demographic group and its growth compared across contractor and 
non-contractor establishments. If affirmative action is effective, the relative occupational index for minorities and females should increase faster at the contractor establishments that bear the affirmative action obligation. Second, to support the summary evidence on occupational status, employment changes within detailed occupations are analyzed. Third, to show the impact of occupational upgrading on earnings, wage equations are estimated as a function of affirmative action pressure. The conclusions of this study are presented in the final section, and the data underlying this research are discussed in the appendix.

\section{Section 1: The Framework for Analysis}

\section{Past Studies}

All past studies of the impact of affrmative action on occupational advance-and there have only been four- have found that while affirmative action increases total black male employment among federal contractors, it does not increase their employment share in the skilled occupations. The first work on this subject, a study of 1186 establishments in 1967 and 1970 by Burman, found the employment impact of affrmative action to be largest in clerical and operative occupations, and negative, though insignificant, for managers. He also found that affrmative action had an insignificant impact on an index of occupational status. A careful and extensive analysis of 40455 establishments in 1966 and 1970 by Ashenfelter and Heckman confirmed Burman's results. Affirmative action led to increases in black males' employment share, but this was largest and most significant among operatives. At the tops of occupational ladders, black males share was estimated to fall relative to that of white males in the contractor sector. Among offcials and managers, and professionals, as well as among service workers, this decline was significant. Overall. Ashenfelter and Heckman found no significant impact of contractor status on the relative occupational position of black workers. Similarly, for a sample of 74563 establishments between 
1970 and 1972, Goldstein and Smith found no strong evidence of changes in occupational status under affrmative action. The most recent of the past studies, and in many ways the most sophisticated econometrically, by Fleckman and Wolpin of 3677 Chicago area establishments between 1972 and 1973, found that black male employment gains were concentrated in blue-collar occupations. They also found that contractors utilized a greater proportion of white males, and fewer blacks and females than did non-contractors in some white-collar occupations.

These four studies, all based on a comparison of EEO-1 forms at contractor and non-contractor establishments in the early years of affirmative action, all agree that affrmative action was ineffective in increasing the employment of black males in skilled occupations. I shall present evidence that this had changed by the late seventies. This difference may reflect the increasing supply of highly educated blacks, as well as a more aggressive enforcement program, in particular the consolidation of enforcement activities into the Office of Federal Contract Compliance Programs (OFCCP) in 1978.

\section{A Model of Affirmative Action as a Tax}

Affirmative action may be thought of as as a tax on the employment of white males in the contractor sector. If they are immobile, white male workers bear the tax burden and their relative wages fall.

Assume the owner of the firm maximizes utility:

$$
M A X U=T(F(m))-T\left(W_{M}\right) m-T\left(W_{F}\right)(1-m)-t(m-\bar{m})-d(1-m)
$$

where

$\mathrm{T} \quad=$ total employment

$\mathrm{m}=$ proportion of white males in $\mathrm{T}$

$\bar{m} \quad=$ average proportion of white males employed in given industry and geographic area 


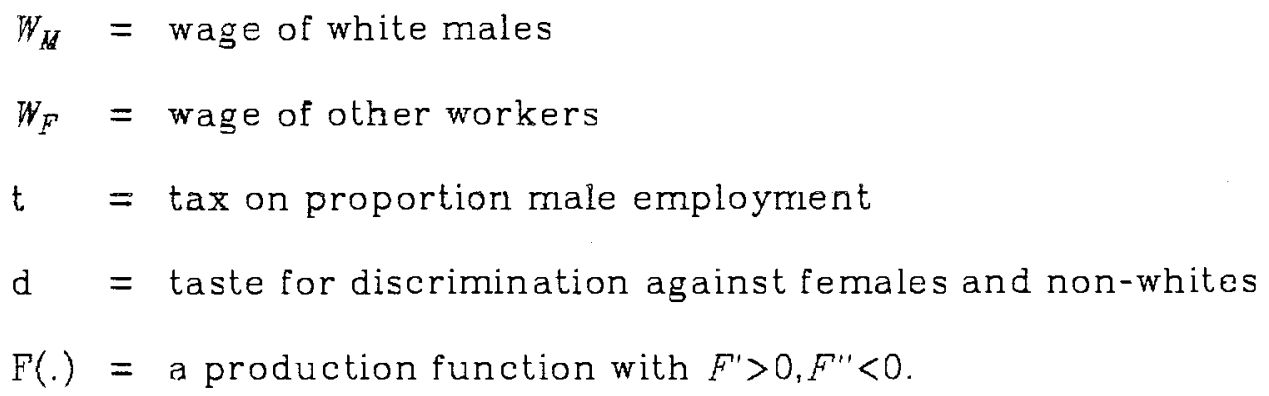

Abstracting from the scale effect by fixing $\mathrm{T}=1$, the first order condition is:

$$
F^{\prime}=W_{H}-W_{F}+t-d
$$

from which we find:

$$
m=g\left(W_{K}, W_{F}, t, d\right)
$$

Intuitively, an increase in the affirmative action 'tax' shifts the demand curve for white male labor down.

I assume fixed tastes for discrimination and fixed technology, or less restrictively, technological change that is neither male nor female saving so that the change in demand is a function only of wages and the tax. All firms are assumed to be wage takers in the same labor market, with the wage elasticity of labor demand the same in the contractor and non-contractor sectors. Empirically, contractor and non-contractor establishments show similar growth rates, so scale effects are likely to be similar. The difference between the change in the employment of white males at contractor firms, $\Delta m_{C}$, and at non-contractor firms, $\Delta m_{N C}$, is then simply a function of affrmative action pressure.

$$
\Delta m_{C}-\Delta m_{N C}=g(t)
$$

This is the central equation to be tested, comparing shifts in the proportional employment of members of protected groups across contractor and non-contractor establishments across time. If affirmative action has been effective, these employment shifts will be greater among contractors. This measures the differential impact of affrmative action over and above the effects of general policies, or changes in tastes. Also, since any general supply shift will affect contractors and non-contractors alike, 
this isolates the impact of affirmative action on labor demand.

\section{Section 2: The Employment Effect of Affirmative Action}

Before examining the impact of affrmative action on occupational advance, it is helpful to analyze changes in total employment by demographic group. This section presents the results of weighted least squares regressions of the change in share of total employment by demographic group as a function of contractor status (C74), review status (REVIEW), establishment size, growth rate, corporate structure, percent non-clerical white-collar, industry, and region. The dependent variable is the change in the employment share of the given demographic group ${ }^{1}$. These equations are estimated on a longitudinal sample of 68690 establishments in 1974 and 1980 which is discussed in the appendix. The sample means of the control variables, and the abbreviations by which they shall be referred in the following tables, are indicated in Table 4.1 .

Table 4.2 shows that blacks' share of employment at contractor establishments grew significantly more than at non-contractor establishments. Between 1974 and 1980, black males' employment share grew significantly more by .11 percentage points at establishments that were contractors in 1974 than at non-contractors. This is an increase of 1.4 percent of black males' initial 1974 employment share in the contractor sector of 7.3 percent, after six years under affrmative action. For black females, contractor status was associated with a significant .14 percentage point increase in employment share, or 3.6 percent of their initial 3.8 percent share of employment. For white females, the increase was .25 percentage points, or 1.0 percent of their initial 24.4 percent share. Contractor establishments did not increase non-black minority employment significantly faster than non-contractors. White males, a summary measure, did significantly worse at contractor establishments.

Table 4.2 also measures the impact of compliance reviews, conditional on contractor status. Compliance reviews contributed to significant percentage point increases 
of .32 for black males, .23 for non-black minority males, and .15 for black females, and significantly retarded the growth in white male and white female representation. Judging by the significant relative decline in white males' employment share at reviewed establishments, compliance reviews have been effective in promoting blacks and minority males, though at the same time they appear to have reduced white females' share of employment 2 .

These estimates suggest an affirmative action program that works for blacks, more so than for other protected groups ${ }^{3}$. Both male and female black employment shares have increased faster at contractor establishments than at non-contractors. and faster at contractors that have completed a compliance review than at nonreviewed contractors.

\section{Section 3: Occupational Detail}

Under Executive Order 11246, federal contractors have an obligation "to take affirmative action to ensure that applicants are employed, and that employees are treated during employment without regard to their race, color, religion, sex or national origin. Such actions shall include, but not be limited to the following: employment, upgrading, demotion or transfer; recruitment or recruitment advertising; layoff or termination: rates of pay or other forms of compensation; and selection for training, including apprenticeship." [41 C.F.R. 169 202(1) (1974)]. The goal of affirmative action is not merely to increase the employment of members of protected groups, but to promote their advancement up the job ladder. A full evaluation of affirmative action requires an examination not only of its effect on total employment, but also of its impact across occupations.

Previous studies suggest that contractors have been able, in practice, to fulfill their affirmative action obligations by hiring more blacks and females in relatively unskilled positions. On this evidence, affirmative action before 1974 appeared to have been more effective in increasing employment than in promoting occupational 
advancement. Some might argue that such a result is only to be expected given the short supply of skilled minorities and females. The presumption behind affirmative action however, is that trainable members of protected groups will be considered for skilled employment. Even in the case of a small fixed supply, in its initial years affrmative action should induce a reshuffling of skilled blacks and women from noncontractor to contractor firms, without any upgrading of individuals necessary.

In Table 4.3 the distribution of minorities and females across occupations is summarized with an index of occupational status. This index weights the proportion of members of a given demographic group in an occupation by the 1969 mean earnings by occupation of full-year employed males from the 1970 Census of Population. If the within occupation variance of wages is small then changes in the occupational index should explain a good deal of overall wage changes. If affirmative action has led to blacks or females being employed in higher paying jobs, then this index should increase faster at contractor firms, under conditions derived below.

The advance of black males under affrmative action does show up in net occupational upgrading. In Table 4.3, black males' occupational index relative to its 1974 value increases 2 percent more in contractor establishments than in non-contractors, and an additional 1 percent in reviewed establishments. ${ }^{4}$ Relative to white males, black males' occupational index has increased 1 percent during six years of affirmative $\operatorname{action}^{5}$. In the equations for occupational index, employment growth by demographic group is controlled for, along with establishment size, corporate structure, industry, region, and lagged employment share. As expected, the higher the employment growth, the lower the rate of occupational advance since many new entrants are at the bottom of occupational ladders ${ }^{6}$.

Between 1974 and 1980 , the ratio of black male to white male mean employment income for full-time, full-year workers increased by 2.3 percent, from .684 to $.700 .^{7}$ Since 69 percent of all employment in the study sample is in contractor establish- 
ments, our results imply that about thirty percent of the increase in the relative economic position of black males may be due to occupational advance induced by affirmative action. While this does not include the effect of promotion within the broad occupational categories used here, it is still likely to be an overestimate both because the study sample probably overstates the proportion of total employment that is in the contractor sector, and because part of the increase in the relative occupational index is probably due to the movement of skilled blacks into the contractor sector, rather than to the advance of blacks within the sector.

\section{Occupational Detail and Occupational Indexes}

While an occupational index provides a dramatic and succinct summary measure, it can be misleading in isolation. For example, the occupational index would increase if firms laid off unskilled blacks or women. This is related to the occupational twist that some have argued affrmative action or anti-discrimination law might induce. To guard against such misinterpretations, the occupational index should be used in conjunction with detailed employment data.

This potential false positive is balanced by a false negative. Any practical occupational index has only a finite level of detail. Much promotion could take place within even detailed occupations. The broader the job classifications, the more upgrading will take place within occupations and so be unobservable. At the extreme, affirmative action could cause massive promotions, but only within job classifications, causing no change at all in an index of occupational status. The initial effect of affirmative action could be to lower the occupational index because new hires are typically hired into jobs at the bottoms of the job ladders.

Even if affrmative action induces an increase in the employment of minorities and females at the top of the job ladder, the occupational index may still decline due to a composition effect. Since $64 \%$ of minority males are employed as operatives and laborers, and $83 \%$ of females are employed as operatives, laborers and offce workers, 
even small proportional employment increases in these occupations will account for a large share of total employment.

To clarify these issues consider the following formalization of the relationship between an occupational index and growth rates within occupations. An occupational index is:

$$
Z_{t}=\sum_{i} W_{i} \alpha_{i t}
$$

where

$Z_{t}$ is the occupational index in year $t$

$W_{i}$ is earnings in occupation $\mathrm{i}$ in a given fixed year

$\alpha_{i j t}$ is the proportion of all workers of a given demographic group $j$ who are employed in occupation $\mathrm{i}$ in year $t, \sum_{i} \alpha_{i t}=1$.

Taking the derivative with respect to time:

$$
\frac{d Z_{t}}{d t}=\sum_{i} W_{i} \frac{d \alpha_{i t}}{d t}
$$

But the side condition on the shares is that:

$$
\sum_{i} \frac{d \alpha_{i t}}{d t}=0
$$

So the occupational index can only increase over time if $\alpha_{i t}$ increases in high wage occupations. However, the occupational index of blacks can decline even though black representation is growing in every occupation. Formally:

$$
Z=\sum W_{i} \frac{N_{i j}}{N_{j}}
$$

and

$$
P_{i}=\frac{N_{i j}}{N_{i}}
$$

where

$N_{i j}=$ number of demographic group jemployed in occupation $\mathrm{i}$ 
$N_{j}=$ number of employees in demographic group $j$

$N_{i}=$ number of employees in occupation i

$$
\alpha_{i}=N_{i j} / N_{j}
$$

Expressing $\mathrm{Z}$ in terms of $P_{i}$ :

$$
Z_{t}=\frac{1}{N_{j}}-\sum_{i} N_{i} W_{i} P_{i t}
$$

To see how $Z_{t}$ changes with changes in $P_{i}$, first totally differentiate:

$$
d Z_{t}=\sum W_{i} d \alpha_{i}
$$

Now

$$
\ln \alpha_{i}=\ln N_{i j}-\ln N_{j}
$$

So

$$
d \ln \alpha_{i}=d \ln \dot{N}_{i j}-d \ln N_{j}
$$

or

$$
d \alpha_{i}=\alpha_{i}\left[d \ln N_{i j}-d \ln N_{j}\right]
$$

So

$$
d Z_{t}=\sum W_{i} \alpha_{i}\left[d l n N_{i j}-d l n N_{j}\right]
$$

To put this in terms of $P_{i}$, note that:

$$
\ln N_{i j}=\ln N_{i}+\ln P_{i}
$$

so

$$
d \ln N_{i j}=d \ln N_{i}+d \ln P_{i}
$$

This gives us:

$$
d Z_{t}=\sum_{i} W_{i} \alpha_{i}\left[d \ln N_{i}+d \ln P_{i}-d l n N_{j}\right]
$$

The condition for no change in the occupational index is then that:

$$
\sum_{i} W_{i} \alpha_{i}\left[d \ln N_{i}+d \ln P_{i}\right]=Z_{t} d \ln N_{j}
$$

If $d \ln P_{i}>0$ across all occupations, then this condition is more likely to hold if: 
(1) dln $N_{i}$ is negative.

(2) The covariances of $W_{i}$ and $\alpha_{i}$ with din $P_{i}$ are negative.

(3) dln $N_{j}$ is large and positive.

In words, the occupational index is more likely to remain unchanged even though minority representation is increasing in all occupations if (1) total employment is declining; (2) earnings and share of minority employment are low where the greatest proportional increases in minority share of employment are high (composition effect); and (3) total employment of minorities is increasing.

What to make of all this? The lesson is not that the occupational index is not useful; but that like any simplifying tool, its use without knowledge of its limitations is potentially misleading. The occupational index is a dramatic and easily understood summary measure, but the full story of the impact of affirmative action requires an analysis of employment data within disaggregated occupations.

\section{Fmployment Shifts Within Occupations}

To test the impact of affrmative action within detailed occupations, I regress the change in employment share on contractor and review status, establishment size, corporate structure, industry, region, and growth of total employment for the given demographic group, in samples of establishments reporting employment in nine occupations and two trainee positions. These regressions are weighted by total initial period employment within the given occupation. The key results from this mass of information are condensed in a set of summary tables by demographic group, Tables 4.4 to 4.7 . In these tables the coefficients on contractor and review status are expressed as a percent of initial 1974 employment share. The evidence is most striking in the case of black males in Table 4.4. In every occupation except laborers and white-collar trainees, black males' share of employment has increased faster in contractor than in non-contractor establishments, and except for operatives and professionals these differences are significant. This impact is found in both the 
proportionate change in black males' share of total employment, and in the proportionate change in the ratio of black male to white male share.

The marginal impact of a compliance review, conditional on contractor status is also shown. The relative importance of being a contractor and of being a reviewed contractor is mixed across occupations, but in every case, except blue-collar trainees and clerks, reviewed establishments have increased black males' employment share more than non-reviewed contractors.

The total impact of the contract compliance program, the weighted sum of contractor and review effects, shows some evidence of a twist in demand toward more highly skilled black males. Since 17.4 percent of all contractor employment is in reviewed establishments, the total impact is calculated as the sum of the contractor effect and .174 times the review effect. The contract compliance program has not reduced the demand for black males in low skilled occupations, except for laborers. It has raised the demand for black males more in the highly skilled white-collar and craft jobs than in the blue-collar operative, laborer, and service occuaptions. While this may help explain why highly skilled black males have been better off than their less skilled brethren, it does not help explain why low skilled black males should be having greater difficulty over the years in finding and holding jobs.

Affirmative action has also helped non-black minority males, although to a lesser extent. Table 4.5 shows evidence of a twist in demand toward Hispanic, Asian, and American Indian males in white-collar occupations, particularly in sales and clerical positions, and away from this group in operative and laborer positions. Compliance reviews have had a strong and significant additional impact in the professional, managerial, and craft occupations. The total impact of the contract compliance program on non-black minority males is positive in the white-collar, craft, and service occupations, and in training programs. Relative to white males, affrmative action has increased the occupational status of non-black minority males by 2 percent. 
The evidence in Table 4.6 suggests that the contract compliance program has had a mixed, and often negative impact on white females. For technical, sales, clerical, craft, and trainee workers, contractor status is associated with a significant decline in white females employment share. Compliance reviews have also often had a negative impact. While both contracts and reviews produce a significant one percent increase in white females' occupational status, this positive impact disappears when changes in white females' occupational status are compared to the relatively greater gains of white males.

Table 4.7 shows that in contrast to whites, black females in contractor establishments have increased their employment share in all occupations except technical, craft, and white-collar trainee. Compliance reviews have had a mixed effect across occupations. The positive impact of the contract compliance program is even more marked when the position of black females is compared with that of white females. Overall, black females' index of occupational status has increased 1 percent relative to that of white females under affrmative action. With the same qualifications as in the male case, this net movement across broad occupations may account for twenty percent of the 3.2 percent increase from .917 in 1974 to .946 in 1980 in the ratio of black female to white female earnings observed in Bureau of the Census data.

The conclusion drawn from this detailed analysis of employment by occupation is that with the exception of white females, affrmative action appears to have contributed to the occupational advance of members of protected groups. In particular, for non-white males affrmative action has increased demand relatively more in the more highly skilled occupations. The finding here that affirmative action has helped move minorities up as well as in stands in contrast to past studies of the early years of affrmative action which found no significant evidence of occupational upgrading. 


\section{The Impact on Racial Inequality in Earnings}

As affirmative action has increased the demand for minorities it has increased their earnings as well as their employment and occupational status. To directly measure wage effects I estimate log-linear wage equations using the May 1978 Current Population Survey sample matched with data on the proportion of employment by industry by SMSA that was in contractor establishments in 1980. The CPS sample is limited to males in non-agricultural employment in the 43 largest SMSA's who reported weekly earnings, hours, and industry of employment. The log-wage equations are estimated separately for white and non-white males, and control for the following personal characteristics: age and its square, years of schooling completed and its square, marital and veteran status, and class of worker. Dummy variables for individual SMSAs, SMSA size, and residence in the central city are also included. Occupation is not controlled for because we are interested not in within occupation wage variation, but in changes across occupations.

As the contractor sector's employment share increases by one standard deviation, non-white male wages increase by eight percent compared to six percent for white males. Both effects are significant, and the impact on non-white males is significantly greater than that on white males according to an F-test across equations. If the occupational upgrading estimated in this paper was due simply to occupational reclassification in name only -title inflation-, then no such wage effect would be expected. This cross-section evidence indicates that occupational advance under affrmative action has contributed to the decline in racial earnings inequality. Black male wages increase relatively more than those of white males in contractor intensive industries. After 1974, affrmative action appears to have increased the employment of non-white males in the more skilled and remunerative occupations ${ }^{8}$. 


\section{Section 4: Conclusion}

This paper has shown that affimative action under Executive Order 11246 has promoted the occupational advance of minorities of both sexes, as well as increasing their employment among government contractors. For white females, the impact of the program appears mixed, and more diffcult to separate from concurrent supply shifts. The finding of occupational advance for black males is reinforced by evidence that affirmative action has narrowed the difference in earnings between the races.

If minorities and females do not share the skills and interests of white males, then perhaps the best one can expect from an affirmative action program is to increase their employment. But to the extent that minorities and females share the qualifications and interests of white males, an effective affirmative action program should improve their chances of sharing the same occupations too.

In the end, this is really a story about a reform that works despite generating considerable resistance. But just as no policy works in isolation, so no policy can be evaluated in isolation. Our major finding here is that affirmative action has increased the demand for minorities in skilled jobs in the contractor sector. The relative demand shift has been greater for skilled than unskilled workers. The success of this program in skilled occupations after 1974, where none had been observed before, is probably due in part to the increasing supply of skilled minorities in many fields, as well as to the more aggressive use of sanctions after the early 1970's. The weaker results for white females must be considered in light of the massive increase in female labor supply that has led to increased female employment throughout the economy, and which may have obscured the contractor effect. We have also seen minorities and females enjoying the greatest gains at growing establishments, both contractor and non-contractor. The lesson drawn is that affrmative action programs work best when they are vigorously enforced, when they work with other policies that augment the skills of members of protected groups, and when they work with growing employers. 


\section{NOTES}

1. While my 2 years of data do not allow a test of serial correlation, Heckman and Wolpin report significant evidence of positive serial correlation of errors on the order of .9 in a similar data set. In cross-section estimates using levels with a lagged dependent this is expected to bias downwards the short run impact of contractor status in the case of black males. The results presented here use a firstdifference in the dependent variable which should reduce potential bias from serial correlation of the magnitude previously reported. The point estimates reported here change in other specifications reported at length in other work, particularly in the case of females, but these do not alter the main conclusions drawn here.

2. On this evidence, compliance reviews appear to be more effective for blacks than for females. This does not mean that female employment is not improving among the reviewed, but rather that it is improving faster among non-reviewed. In any case, a weaker result for females than for minorities is consistent with compliance reviews that ask for more than last year, rather than more than average, during a period of rapidly increasing female labor supply.

3. To determine the within industry, within region impact of affrmative action all of the equations in Table 4.2 include 27 industry dummy variables and 4 region dummy variables. Some of these variables had significant and large effects. Southern establishments showed smaller increases in white male and white female employment share. These estimates imply that black employment is growing faster in the South, and that racial discrimination is not obviously worse there.

There is also significant variation in the growth of minority and female representation across industries. White males' employment share, a summary measure, has grown significantly faster in mining, construction, lumber, paper, stone, clay 
and glass, primary and fabricated metals, non-electrical machinery, transportation equipment, transportation, and public utilities. Black males' share has grown significantly slower in apparel, non-electrical machinery, and miscellaneous manufacturing. White females' share has grown significantly slower in agriculture, construction, paper, primary metals, and transportation. Since region, growth rate, and percent non-clerical white collar are controlled for, these appear to reflect real differences across sectors in the growth of minority and female representation.

Controlling for whether or not the establishment was part of a multiestablishment corporation - corporate status- reduces the difference between contractor and non-contractor establishments. Establishments that were part of larger corporations had significantly larger increases in female and black male employment. Establishment size itself works in the opposite direction, black males experienced significantly slower growth in representation at larger establishments. Establishments that are growing and so have many job openings showed significant increases in minority and female representation. White females, but not other groups, experienced significantly and substantially greater employment growth at establishments that were white-collar intensive.

Other specifications not shown here tested for interactions of contractor and review status with size, growth and initial minority or female representation. There are few recurrent patterns. The data give no clear answer to the question of how the impact of contractor status varies by the establishrnent's initial employment of minoritics and females. There is evidence that affrmative action for black males has been more effective at male intensive establishments.

4. The coefficients of interest here, on contractor and review status, do not change significantly when the equations for black and white males are reestimated on a larger sample of 41660 establishments with just the restrictions that black male 
and white male employment be positive.

5. This does not include within occupation promotions, which are substantial within such broadly defined occupations. It also refers to the changing net position of black males at the average establishment, not to the average career transition of the average black male. In particular, since our unit of observation is the establishment, no individual black male need move to a higher occupation for the index at the average contractor establishment to increase, if many highly skilled blacks migrate into the contractor sector. Of course, it is very unlikely that all of the increase in the occupational index is due to such cross-sector migration.

6 For all groups, the faster the growth in total employment, the lower the occupational status. This effect appears strongest for white females and for non-black minority males. while it is weaker and less significant for white males and black females. This coeffcient measures the difference in occupational status of members of a given demographic group across establishments with fast and slow growth of that group. As such, attempts to use it for cross-group comparisons must be interpreted with care. In particular, the mean occupational status of each group must be considered. For example, while the effects of growth on occupational status is relatively small for both white males and black females, a plausible interpretation in the first case is that white male new entrants are being employed in positions nearly as high as those of in place white males, while in the second case a plausible interpretation is that black female new entrants are being employed in positions nearly as low as those in place. In each case the coefficient tells us only how the occupational status differs from that of the average worker of the same group.

7. Earnings of full-time workers employed 50-52 weeks from U.S. Bureau of the Census, Current Population Reports, Series P-60, "Money Income in 1974 of Families and Persons in the U.S.", no. 101, January,1976, Table 61, p.127. and from 
U.S. Bureau of the Census, Current Population Reports, Series P-60, "Money Income in 1974 of Fouseholds, Families, and Persons in the U.S.", no. 132, July, 1982, Table 59, p.213,214.

8. A companion paper addresses these wage equations at greater length. The wage effects have been growing over time in both size and significance, as one might expect from increasingly powerful enforcement. The contractor effect was insignificant for white males in 1969, but significant for non-white males, and significant for both in 1973 . In both these previous years, the effect on non-white males' earnings was significantly greater than on white males. If orse puts great weight on the previous employment studies, this may perhaps indicate a peculiar omitted variable bias in the wage equations that differentially affects blacks and that grows over time. Alternatively, these wage equations may indicate an affirmative action program that since 1969 has helped reduce racial wage inequality and promoted black male occupational advance. 


\section{BIBLIOGRAPHY}

Ashenfelter, Orley and Heckman, James. "Measuring the Effect of an Antidiscrimination Program" in Orley Ashenfelter and James Blum, eds., Evaluating the Labor Market Effects of Social Programs, (Princeton: Industrial Relations Section, Princeton University, 1976), pp. 46-84.

Burman, George. The Economics of Discrimination: The Impact of Public Policy. unpublished Ph.D. thesis, Graduate School of Business, University of Chicago, 1973.

Flanagan, Robert J. "Actual Versus Potential Impact of Government Antidiscrimination Programs," Industrial and Labor Relations Review, vol. 29, no. 4, July 1976, pp. 486-507.

Freeman, Richard B. "Changes in the Labor Market for Black Americans, 1948-1970", Brookings Papers, 1973, no. 1, pp. 67.-120.

Goldstein, Morris and Smith, Robert S. "The Estimated Impact of the Antidiscrimination Program Aimed at Federal Contractors," Industrial and Labor Relations Review, vol. 29, no. 4, July 1976, pp. 523-543.

Heckman, James J. and Butler, Richard. "The Government's Impact on the Labor Market Status of Black Americans: A Critical Review," in Leonard Hausman et. al. ed., Equal Rights and Industrial Relations, (Madison: Industrial Relations Research Association, 1977).

Heckman, James J. and Wolpin, Kenneth I. "Does the Contract Compliance Program Work? An Analysis of Chicago Data," Industrial and Labor Relations Review, vol. 29, no. 4, July 1976, pp. 544-564.

Johnson, George and Welch, Finis. "The Labor Market Implications of an Economy-wide Affirmative Action Program" Industrial and Labor Relations Review, vol. 29, no. 4 , pp. 508-522. 
Leonard, Jonathan. "The Impact of Affrmative Action", U.S. Department of Labor report, July, 1983.

Smith, James and Finis Welch, "Black-White Male Wage Ratios: 1960-1970", American Economic Review, vol. 67, no. 3, pp. 323-338.

U.S. Department of Labor, Office of Federal Contract. Compliance Programs, Freedom of Information Act Index, June 1980 and April 1981.

U.S. Equal Employment Opportunity Commission. EEOC Report: Minorities and Women in Private Industry, Annual Volumes. 


\section{Appendix: Data}

This study developed a new and detailed longitudinal data set based on establishment level demographic data from EEO-1 reports made available by the OFCCP's Division of Program Analysis. Title VII of the Civil Rights Act of 1964 requires annual reports on workforce demographics from all private employers with 100 or more employees, or 50 or more employers and a federal contract or first-tier subcontract worth $\$ 50,000$ or more. In the case of multi-plant employers, all establishments with more than 24 employees that belong to firms fulfilling the above conditions must report individually. Employers with small or temporary workforces such as construction, trade and agriculture are underrepresented.

From samples of roughly 160,000 establishments in 1980 and 100,000 establishments in 1974 I found 68,690 establishments that filed identifiable reports in both years. The empirical tests comparing contractors with non-contractors are based on these 68,690 establishments with more than sixteen million employees from the matched sample. The detailed occupational tests are based on subsamples reporting positive employment within the occupation.

An establishment is considered a contractor if the company or any of its establishments are prime government contractors or first-tier subcontractors with a contract, subcontract or purchase order of $\$ 50,000$ or more. Any such establishment is identified as a contractor, whether or not the establishment so identified itself.

Contractors appear to have become better labeled over time. Twenty-seven percent of all 1974 non-contractors were identified as contractors in 1980, constituting seventeen percent of all 1980 contractors. Whether these status changes are true, or just an artifact of more accurate reporting, my results will be biased against finding any affirmative action effect when I test according to 1974 status only.

To the extent that contractors may have selectively reclassified upwards black and female intensive detailed occupations at a faster rate than did non-contractors, 
this study and its predecessors will overstate the actual occupational advance due to affirmative action. Of course pure reclassification would cause black losses in the lower occupations, which is generally not observed.

To compare demographic changes across reviewed and non-reviewed establishments I merged the matched 1974 and 1980 EEO-1 establishment demographic data with data on OFCCP compliance reviews. OFCCP administrative records contain data on 27,000 compliance reviews across 13,000 identifiable establishments, between 1973 and 1981. These are almost exclusively Department of Defense compliance reviews, which account for nearly half of all reviews. Reviews completed prior to 1973 or after 1979 are underrepresented, and due to general under-reporting some establishments that were reviewed will be included among the non-reviewed, biasing my tests against finding an impact of compliance reviews. I labeled as reviewed any establishments that had a record of at least one compliance review between 1975 and 1979 inclusive. Multiple reviews are not rare, but are not controlled for in my tests. Since the mode year of review completion in the sample is 1975 , while demographic changes are measured between 1974 and 1980, there is little potential for underestimating review effects due to lags in response. 
Table 4.1: Variable Definitions, Means, and Standard Deviations $\mathbf{N}=68690$

\begin{tabular}{|c|c|c|c|}
\hline $\begin{array}{l}\text { Variable } \\
\text { Name }\end{array}$ & Mean & $\begin{array}{l}\text { Standard } \\
\text { Deviation }\end{array}$ & Definition \\
\hline $\mathrm{C74}$ & .601 & .49 & $\begin{array}{l}=1 \text { if establishment was part of a } \\
\text { contractor company in } 1974\end{array}$ \\
\hline REVIEW & .041 & .20 & $\begin{array}{l}=1 \text { if establishment completed a } \\
\text { compliance review between } 1974 \text { and } \\
1980 \text { exclusive. }\end{array}$ \\
\hline SIZE & .237 & .594 & Total number of employees in 1974 , in thousands. \\
\hline $\mathrm{SIZE}^{2}$ & .409 & 7.46 & Size squared. \\
\hline GROWTH & .197 & 1.67 & $\begin{array}{l}\text { Rate of growth of total employment } \\
\text { from } 1974 \text { to } 1980 .\end{array}$ \\
\hline SINGLE & .183 & .39 & $\begin{array}{l}=1 \text { if establishment was not part of } \\
\text { a multi-establishment company. }\end{array}$ \\
\hline PWC & .381 & .31 & $\begin{array}{l}\text { Proportion of all employees who are } \\
\text { officials, managers, professionals, } \\
\text { technicians and sales people. }\end{array}$ \\
\hline
\end{tabular}


Table 4.2: Weighted Least Squares Regressions of the Effect of Contractor and Review Status on the Change in the Percent Employed by Demographic Group, 1974-1980.

$\mathbf{N}=68690$

\begin{tabular}{|c|c|c|c|c|c|}
\hline $\begin{array}{l}\text { Demographic } \\
\text { Group: }\end{array}$ & $\begin{array}{l}\text { White } \\
\text { Males }\end{array}$ & $\begin{array}{l}\text { Black } \\
\text { Males }\end{array}$ & $\begin{array}{l}\text { Other } \\
\text { Males }\end{array}$ & $\begin{array}{l}\text { White } \\
\text { Females }\end{array}$ & $\begin{array}{c}\text { Black } \\
\text { Females }\end{array}$ \\
\hline Equation: & 1 & 2 & 3 & 4 & 5 \\
\hline C74 & $\begin{array}{c}-.0061 \\
(.0009)\end{array}$ & $\begin{array}{l}.0011 \\
(.0004)\end{array}$ & $\begin{array}{c}.0002 \\
(.0004)\end{array}$ & $\begin{array}{c}.0025 \\
(.0008)\end{array}$ & $\begin{array}{c}.0014 \\
(.0004)\end{array}$ \\
\hline REVIEW & $\begin{array}{c}-.0032 \\
(.0011)\end{array}$ & $\begin{array}{c}.0032 \\
(.0005)\end{array}$ & $\begin{array}{l}.0023 \\
(.0005)\end{array}$ & $\begin{array}{c}-.0035 \\
(.0010)\end{array}$ & $\begin{array}{l}.0015 \\
(.0005)\end{array}$ \\
\hline SIZE & $\begin{array}{l}.00095 \\
(.0003)\end{array}$ & $\begin{array}{c}-.0001 \\
(.0001)\end{array}$ & $\begin{array}{c}-.00066 \\
(.0001)\end{array}$ & $\begin{array}{c}-.0005 \\
(.0002)\end{array}$ & $\begin{array}{l}.0003 \\
(.0001)\end{array}$ \\
\hline $\operatorname{SIZE}^{2}$ & $\begin{array}{l}-.00006 \\
(.000017)\end{array}$ & $\begin{array}{c}.000006 \\
(.000006)\end{array}$ & $\begin{array}{l}.00003 \\
(.000006)\end{array}$ & $\begin{array}{c}.00003 \\
(.00001)\end{array}$ & $\begin{array}{r}-6.46 \times 10^{-7} \\
\left(5.8 \times 10^{-6}\right)\end{array}$ \\
\hline GROWTH & $\begin{array}{c}-.0073 \\
(.0004)\end{array}$ & $\begin{array}{c}.0018 \\
(.0002)\end{array}$ & $\begin{array}{c}.0007 \\
(.0002)\end{array}$ & $\begin{array}{l}.0019 \\
(.0004)\end{array}$ & $\begin{array}{c}.0019 \\
(.0002)\end{array}$ \\
\hline SINGI.F & $\begin{array}{c}.0094 \\
(.0010)\end{array}$ & $\begin{array}{c}-.0014 \\
(.0005)\end{array}$ & $\begin{array}{c}.0031 \\
(.0004)\end{array}$ & $\begin{array}{c}-.0081 \\
(.0009)\end{array}$ & $\begin{array}{c}-.0042 \\
(.0005)\end{array}$ \\
\hline PWC & $\begin{array}{c}-.039 \\
(.002)\end{array}$ & $\begin{array}{c}.0067 \\
(.0008)\end{array}$ & $\begin{array}{l}.00024 \\
(.0008)\end{array}$ & $\begin{array}{l}.028 \\
(.0015)\end{array}$ & $\begin{array}{c}.0026 \\
(.0008)\end{array}$ \\
\hline MSE & 1.63 & .37 & .35 & 1.41 & .36 \\
\hline
\end{tabular}

Note: All equations include 27 Industry and 4 Region Dummies, and are weighted by establishment size in 1974 . 
Table 4.3: Index of Occupational Status.

OLS Equations of the Effect of Contractor and Review Status on Occupational Index by Demographic Group. $\mathrm{N}=13936$

\begin{tabular}{|c|c|c|c|c|c|}
\hline $\begin{array}{l}\text { Demographic } \\
\text { Group: } \\
\text { Equation: }\end{array}$ & $\begin{array}{l}\text { White } \\
\text { Males } \\
1\end{array}$ & $\begin{array}{l}\text { Black } \\
\text { Males } \\
\quad 2\end{array}$ & $\begin{array}{l}\text { Other } \\
\text { Males } \\
3\end{array}$ & $\begin{array}{c}\text { White } \\
\text { Females } \\
4\end{array}$ & $\begin{array}{c}\text { Black } \\
\text { Females } \\
5\end{array}$ \\
\hline C74 & $\begin{array}{c}50.9 \\
(12.8)\end{array}$ & $\begin{array}{l}120.6 \\
(18.6)\end{array}$ & $\begin{array}{l}204.4 \\
(24.1)\end{array}$ & $\begin{array}{c}41.3 \\
(11.5)\end{array}$ & $\begin{array}{c}84.3 \\
(15.7)\end{array}$ \\
\hline REVIEW & $\begin{array}{c}60.4 \\
(19.0)\end{array}$ & $\begin{array}{c}98.9 \\
(27.6)\end{array}$ & $\begin{array}{l}102.1 \\
(35.9)\end{array}$ & $\begin{array}{c}54.6 \\
(17.1)\end{array}$ & $\begin{array}{c}26.5 \\
(23.3)\end{array}$ \\
\hline $074 *$ & $\begin{array}{l}.82 \\
(.005)\end{array}$ & $\begin{array}{l}.62 \\
(.006)\end{array}$ & $\begin{array}{l}.60 \\
(.006)\end{array}$ & $\begin{array}{l}.83 \\
(.006)\end{array}$ & $\begin{array}{l}.63 \\
(.007)\end{array}$ \\
\hline SIZE & $\begin{array}{c}.0011 \\
(.005)\end{array}$ & $\begin{array}{c}-.010 \\
(.007)\end{array}$ & $\begin{array}{c}.022 \\
(.009)\end{array}$ & $\begin{array}{l}.006 \\
(.004)\end{array}$ & $\begin{array}{l}.005 \\
(.006)\end{array}$ \\
\hline$G^{* *}$ & $\begin{array}{c}-8.50 \\
(1.40)\end{array}$ & $\begin{array}{c}-16.9 \\
(2.0)\end{array}$ & $\begin{array}{r}-21.3 \\
(2.5)\end{array}$ & $\begin{array}{r}-26.5 \\
(2.5)\end{array}$ & $\begin{array}{c}-6.90 \\
(1.3)\end{array}$ \\
\hline SINGLE & $\begin{array}{c}30.88 \\
(14.40)\end{array}$ & $\begin{array}{r}-150.7 \\
(21.0)\end{array}$ & $\begin{array}{c}-42.9 \\
(27.2)\end{array}$ & $\begin{array}{c}12.8 \\
(13.0)\end{array}$ & $\begin{array}{l}-53.4 \\
(17.7)\end{array}$ \\
\hline $\mathrm{R}^{2}$ & .71 & .50 & .47 & .69 & .49 \\
\hline MSE & 338,731 & 713,418 & $1,203,759$ & 273,348 & 509,357 \\
\hline $\begin{array}{l}\text { mean of the } \\
\text { dependent } \\
\text { variable. }\end{array}$ & 9258 & 8152 & 8663 & 8510 & 7977 \\
\hline
\end{tabular}

Note: All equations include 27 Industry and 4 Regional Dummies. Sample limited to establishments with at least one employee in each Demographic Group. Standard Errors in Parentheses.

* 074 is the lagged dependent variable: the index of occupational status for the given demographic group in 1974.

* $\mathrm{G}$ is the rate of growth of total employment of the given Demographic Group between 1974 and 1980 . 
Table 4.4: Summary of the Impact of Contractor and Review Status on the Change in Black Male Employment by Occupation.

\begin{tabular}{|c|c|c|c|c|c|c|c|}
\hline Occupation & $\begin{array}{c}\% \text { of all } \\
\text { Black } \\
\text { Males in } \\
\text { Occupation } \\
\text { in } 1974\end{array}$ & $\begin{array}{r}\text { Elasticity } \\
\text { Males'Sha } \\
\text { Respec } \\
\text { Contractor } \\
\text { Status }\end{array}$ & $\begin{array}{l}\text { Black } \\
\text { e With } \\
\text { to: } \\
\text { Review } \\
\text { Status }\end{array}$ & Total & $\begin{array}{c}\text { Elasticity o } \\
\text { Black Male } \\
\text { Male Sha } \\
\text { Respec } \\
\text { Contractor } \\
\text { Status }\end{array}$ & $\begin{array}{l}\text { Ratio of } \\
\text { o White } \\
\text { with } \\
\text { to: } \\
\text { Review } \\
\text { Status }\end{array}$ & Total \\
\hline $\begin{array}{l}\text { 1. Offcials and } \\
\text { Managers }\end{array}$ & .030 & $.09 * *$ & $.08 *$ & .10 & .10 & .08 & .11 \\
\hline 2. Professionals & .015 & .08 & .07 & .09 & .12 & .07 & .13 \\
\hline 3. Technicians & .020 & $.08^{*}$ & .05 & .09 & .08 & .05 & .09 \\
\hline 4. Sales & .032 & $.19 * *$ & .14 & .21 & .20 & .20 & .23 \\
\hline 5. Clerical & .032 & $.10^{* *}$ & -.04 & .09 & .11 & -.04 & .10 \\
\hline 6. Craft & .119 & $.11^{* *}$ & $.06 * *$ & .12 & .11 & .07 & .12 \\
\hline 7. Operatives & .418 & .004 & .008 & .005 & .016 & .017 & .019 \\
\hline 8. Laborers & .198 & -.016 & .03 & -.011 & -.005 & .003 & -.004 \\
\hline 9. Service & .137 & $.02 *$ & .007 & .02 & .06 & .13 & .08 \\
\hline $\begin{array}{l}\text { 10. Trainees- } \\
\text { White Collar }\end{array}$ & .003 & -.08 & $.45^{*}$ & -.002 & -.09 & .45 & -.003 \\
\hline $\begin{array}{l}\text { 11. Trainees- } \\
\text { Blue Collar }\end{array}$ & .106 & .04 & -.07 & .03 & .05 & -.08 & .04 \\
\hline $\begin{array}{l}\text { 12. Occupational } \\
\text { Index }\end{array}$ & - & $.02^{* *}$ & $.01 * *$ & .02 & .01 & .006 & .01 \\
\hline
\end{tabular}


Table 4.5: Summary of the Impact of Contractor and Review Status on Non-Black Minority Male Employment by Occupation.

\begin{tabular}{|c|c|c|c|c|c|c|c|}
\hline Occupation & $\begin{array}{c}\% \text { of all } \\
\text { Other } \\
\text { Males in } \\
\text { Occupation } \\
\text { in } 1974\end{array}$ & $\begin{array}{c}\text { Elasticity } \\
\text { Males' Sha } \\
\text { Respec } \\
\text { Contractor } \\
\text { Status }\end{array}$ & $\begin{array}{l}\text { Other } \\
\text { e With } \\
\text { to: } \\
\text { Review } \\
\text { Status }\end{array}$ & Total & $\begin{array}{c}\text { Other Male } \\
\text { Male Shar } \\
\text { Respec } \\
\text { Contractor } \\
\text { Status }\end{array}$ & $\begin{array}{l}\text { Do White } \\
\text { e with } \\
\text { to: } \\
\text { Review } \\
\text { Status }\end{array}$ & Total \\
\hline $\begin{array}{l}\text { 1. Offcials and } \\
\text { Managers }\end{array}$ & .048 & $.05 *$ & $.10 * *$ & .07 & .06 & .10 & .08 \\
\hline 2. Professionals & .057 & $.14^{* *}$ & $.17^{* *}$ & .17 & .18 & .17 & .21 \\
\hline 3. Technicians & .035 & .06 & -.04 & .05 & .06 & -.04 & .05 \\
\hline 4. Sales & .052 & $.15^{* *}$ & $.22^{*}$ & .19 & .16 & .28 & .21 \\
\hline 5. Clerical & .044 & $.14^{* *}$ & $.16^{*}$ & .17 & .15 & .15 & .18 \\
\hline 6. Craft & .159 & .03 & $.08 * *$ & .04 & .03 & .09 & .05 \\
\hline 7. Operatives & .300 & -.04 & .03 & -.03 & -.03 & .04 & -.02 \\
\hline 8. Laborers & .193 & $-.08 * *$ & -.03 & -.09 & -.07 & -.06 & -.08 \\
\hline 9. Service & .110 & .02 & .08 & .03 & .01 & .21 & .05 \\
\hline $\begin{array}{l}\text { 10. Trainees- } \\
\text { White Collar }\end{array}$ & .002 & $.92^{* *}$ & $-.88 * *$ & .78 & .90 & -.99 & .73 \\
\hline $\begin{array}{l}\text { 11. Trainees- } \\
\text { Blue Collar }\end{array}$ & .006 & .23 & .04 & .24 & .25 & .02 & .25 \\
\hline $\begin{array}{l}\text { 12. Occupational } \\
\text { Index }\end{array}$ & - & $.02^{* *}$ & $.01 * *$ & .02 & .02 & .01 & .02 \\
\hline
\end{tabular}


Table 4.6: Summary of the Impact of Contractor and Review Status on White Female Employment by Occupation.

\begin{tabular}{|c|c|c|c|c|c|c|c|}
\hline & $\begin{array}{c}\% \text { of all } \\
\text { White } \\
\text { Fermales in }\end{array}$ & $\begin{array}{r}\text { Elasticity } \\
\text { Females' Sh } \\
\text { Respec }\end{array}$ & $\begin{array}{l}\text { f White } \\
\text { are With } \\
\text { to: }\end{array}$ & & $\begin{array}{c}\text { Elasticity } \\
\text { White Fer } \\
\text { White Mal } \\
\text { with Res }\end{array}$ & $\begin{array}{l}\text { Ratio of } \\
\text { ale to } \\
\text { Share } \\
\text { ct to: }\end{array}$ & \\
\hline Occupation & $\begin{array}{c}\text { Occupation } \\
\text { in } 1974\end{array}$ & $\begin{array}{c}\text { Contractor } \\
\text { Status }\end{array}$ & $\begin{array}{l}\text { Review } \\
\text { Status }\end{array}$ & Total & $\begin{array}{c}\text { Contractor } \\
\text { Status }\end{array}$ & $\begin{array}{l}\text { Review } \\
\text { Status }\end{array}$ & Total \\
\hline 1. Officials and & & & & & & & \\
\hline Managers & .037 & $.06^{*}$ & .008 & .06 & .06 & .01 & .06 \\
\hline 2. Professionals & .083 & $.06 * *$ & -.01 & .06 & .09 & -.01 & .09 \\
\hline 3. Technicians & .049 & -.003 & .006 & -.002 & -.004 & .01 & -.002 \\
\hline 4. Sales & .133 & $-.04 * *$ & $.11 * *$ & -.02 & -.03 & .16 & -.002 \\
\hline 5. Clerical & .299 & $-.007 * *$ & $-.008 *$ & -.008 & .0002 & -.013 & -.002 \\
\hline 6. Craft & .024 & -.04 & -.007 & -.04 & -.04 & -.001 & -.04 \\
\hline 7. Operatives & .195 & $.03 * *$ & $-.03 * *$ & .02 & .05 & -.02 & .05 \\
\hline 8. Laborers & .069 & $.06^{* *}$ & $-.23 * *$ & .02 & .07 & -.26 & .02 \\
\hline 9. Service &. .111 & $.03 * *$ & $.13^{* *}$ & .05 & .06 & .26 & .11 \\
\hline $\begin{array}{l}\text { 10. Trainees- } \\
\text { White Collar }\end{array}$ & .002 & -.03 & -.05 & -.04 & -.05 & -.06 & -.06 \\
\hline $\begin{array}{l}\text { 11. Trainees- } \\
\text { Blue Collar }\end{array}$ & .002 & -.13 & -.13 & -.15 & -.12 & -.14 & -.14 \\
\hline $\begin{array}{l}\text { 12. Occupational } \\
\text { Index }\end{array}$ & - & $.01 * *$ & $.01 * *$ & .01 & -.00 & .00 & -.00 \\
\hline
\end{tabular}


Table 4.7: Summary of the Impact of Contractor and Review Status on Black Female Employment by Occupation.

\begin{tabular}{|c|c|c|c|c|c|c|c|}
\hline \multirow[b]{2}{*}{ Occupation } & \multirow{2}{*}{$\begin{array}{l}\% \text { of all } \\
\text { Black } \\
\text { Females in } \\
\text { Occupation } \\
\text { in } 1974\end{array}$} & \multicolumn{2}{|c|}{$\begin{array}{c}\text { Elasticity of Black } \\
\text { Females'Share With } \\
\text { Respect to: }\end{array}$} & \multicolumn{4}{|c|}{$\begin{array}{c}\text { Black Female to } \\
\text { White Female Share } \\
\text { with Respect to: }\end{array}$} \\
\hline & & $\begin{array}{c}\text { Contractor } \\
\text { Status }\end{array}$ & $\begin{array}{l}\text { Review } \\
\text { Status }\end{array}$ & Total & $\begin{array}{c}\text { Contractor } \\
\text { Status }\end{array}$ & $\begin{array}{l}\text { Review } \\
\text { Status }\end{array}$ & Total \\
\hline $\begin{array}{l}\text { 1. Officials and } \\
\text { Managers }\end{array}$ & .015 & .07 & -.13 & .05 & .007 & -.14 & -.017 \\
\hline 2. Professionals & .026 & $.18 * *$ & $-.16^{*}$ & .15 & .11 & -.15 & .08 \\
\hline 3. Technicians & .051 & $-.13^{* *}$ & $.12^{*}$ & -.11 & -.13 & .11 & -.11 \\
\hline 4. Sales & .061 & $.19 * *$ & -.27 & .14 & .24 & -.34 & .18 \\
\hline 5. Clerical & .190 & $.05^{*}$ & .05 & .06 & .05 & .05 & .06 \\
\hline 6. Craft & .024 & $-.29 * *$ & $-.19^{*}$ & -.32 & $-.27^{*}$ & -.18 & -.30 \\
\hline 7. Operatives & .276 & $.08 * *$ & $.17 * *$ & .11 & .05 & .21 & .09 \\
\hline 8. Laborers & .112 & $.24^{* *}$ & $.19^{* *}$ & .27 & .18 & .55 & .28 \\
\hline 9. Service & .245 & $.08^{* *}$ & $.17^{* *}$ & .11 & .05 & .16 & .08 \\
\hline $\begin{array}{l}\text { 10. Trainees- } \\
\text { White Collar }\end{array}$ & .003 & $-1.01^{* *}$ & .32 & -.94 & -1.05 & .39 & -.98 \\
\hline $\begin{array}{l}\text { 11. Trainees- } \\
\text { Blue Collar }\end{array}$ & .004 & .08 & .02 & .08 & .24 & .18 & .27 \\
\hline $\begin{array}{l}\text { 12. Occupational } \\
\text { Index }\end{array}$ & - & $.01 * *$ & .00 & .01 & .01 & -.00 & .01 \\
\hline
\end{tabular}

